\title{
Effect of Different land Configurations and Sowing Techniques on Yield, Yield Attributes, Quality and Economics of Soybean
}

\author{
M. D. Gadakh ${ }^{1 *}$, K. B. Navale ${ }^{1}$, U. S. Surve ${ }^{1}$, Sonal Athnere ${ }^{1}$ and A. D. Surashe ${ }^{2}$ \\ ${ }^{1}$ Department of Agronomy, ${ }^{2}$ Department of Plant Physiology, M.P.K.V., Rahuri, India \\ *Corresponding author
}

\section{Keywords}

Soybean, Land configuration, Sowing technique, Yield attributes, Economics

\section{Article Info}

Accepted: 04 August 2020 Available Online: 10 September 2020

A field experiment entitled "Standardization of optimum seed rate and yield maximization in soybean under different land configurations and sowing techniques" was undertaken during kharif, 2018 at Post Graduate Instructional Farm, Mahatma Phule Krishi Vidyapeeth, Rahuri, Dist. Ahmednagar (Maharashtra). The experiment consists of eight treatments involving Preparation of ridges and furrows at $45 \mathrm{~cm}$ distance and sowing at one side $(45 \mathrm{~cm} \times 10 \mathrm{~cm})$, Preparation of ridges and furrows at $45 \mathrm{~cm}$ distance and sowing at both side $(22.5 \mathrm{~cm} \times 10 \mathrm{~cm})$, Preparation of ridges and furrows at $60 \mathrm{~cm}$ distance and sowing at one side $(60 \mathrm{~cm} \times 10 \mathrm{~cm})$, Preparation of ridges and furrows at $60 \mathrm{~cm}$ distance and sowing at both side $(30 \mathrm{~cm} \times 10 \mathrm{~cm})$, Preparation of ridges and furrows at $90 \mathrm{~cm}$ distance and sowing at both side $(45 \mathrm{~cm} \times 10 \mathrm{~cm})$, Preparation of BBF [90 $\mathrm{cm}$ top and $120 \mathrm{~cm}$ base] and sowing at $22.5 \mathrm{~cm}$ distance $(22.5 \mathrm{~cm} \times 10 \mathrm{~cm})$. Preparation of BBF [90 $\mathrm{cm}$ top and $120 \mathrm{~cm}$ base] and sowing at $30 \mathrm{~cm}$ distance $(30 \mathrm{~cm} \times 10 \mathrm{~cm})$, Flat bed $(45 \mathrm{~cm} \times 10 \mathrm{~cm})$. The experiment was laid out in randomized block design with three replications. The result revealed that the yield contributing characters recorded at harvest viz. number of pod plant $^{-1}(56)$, pod weight plant ${ }^{-1}(16.80 \mathrm{~g})$. Weight of seeds pod ${ }^{-1}(15.36 \mathrm{~g}), 100$ grain (12 g) weight was obtained highest on $60 \mathrm{~cm}$ ridges and furrows sowing at one side $(60 \mathrm{~cm} \mathrm{x}$ $10 \mathrm{~cm})$ with seed rate $28.1 \mathrm{~kg} \mathrm{ha}^{-1}$. Significantly the highest grain yield $\left(30.60 \mathrm{q} \mathrm{ha}^{-1}\right)$, straw yield $\left(38.86 \mathrm{q} \mathrm{ha}^{-1}\right)$ were recorded on $60 \mathrm{~cm}$ ridges and furrows sowing at two side $(30 \mathrm{~cm}$ $\mathrm{x} 10 \mathrm{~cm})$ with seed rate $51.4 \mathrm{~kg} \mathrm{ha}^{-1}$.The quality parameter, protein content $(40.23)$ was recorded highest on $60 \mathrm{~cm}$ ridges and furrows sowing at one side $(60 \mathrm{~cm} \times 10 \mathrm{~cm})$ with seed rate $28.1 \mathrm{~kg} \mathrm{ha}^{-1}$.The protein content was significantly influenced by different land configuration and sowing techniques and recorded highest on $60 \mathrm{~cm}$ ridges and furrows sowing at one side $(60 \mathrm{~cm} \times 10 \mathrm{~cm})$ with seed rate $28.1 \mathrm{~kg} \mathrm{ha}^{-1}$. The highest gross returns (Rs.117154 ha ${ }^{-1}$ ) and net monetary returns (Rs. $65806 \mathrm{ha}^{-1}$ ) were recorded on $60 \mathrm{~cm}$ ridges and furrows sowing at two side $(30 \mathrm{~cm} \times 10 \mathrm{~cm})$ with seed rate $51.4 \mathrm{~kg} \mathrm{ha}^{-1}$. The similar trend was observed in case of benefit: cost ratio. The highest benefit: cost ratio (2.27) recorded with $60 \mathrm{~cm}$ ridges and furrows sowing at two side $(30 \mathrm{~cm} \times 10 \mathrm{~cm})$ with seed rate $51.4 \mathrm{~kg} \mathrm{ha}^{-1}$.

\section{Introduction}

Soybean [Glycine $\max (\mathrm{L})$ Merill] is an important legume crop belonging to the family Leguminosae, sub family Papilionaceae and genus Glycine. Soybean is diploid species having chromosomes number $2 \mathrm{n}=40$. The origin of soybean is china. It is 
annual leguminous herbaceous plant.

Soybean is cheapest and richest source of protein (38 to $42 \%$ ) except methionine and cysteine and about $20 \%$ oil. It has established its recognition as both pulses and oilseed crop. It supplies most of the nutritional constituents essential for human health. Soybean protein contains all the essential amino acids vital for human diet. Soybean contains less starch and thus good for diabetic patients. Its oil is used as cooking medium and also soybean oil is used for preparation of vanaspati ghee. It is also used in industries for preparation of antibiotics. The protein of meat, fish, eggs and pulses are acid producing while that of soybean are alkalizing in their effects which makes it a desirable constituent of human diet. Soybean is generally processed for its oil, protein and lecithin as a whole bean or particularly/fully defatted cake meal. Soya flour can also be used in making baked products (Chapatis, biscuits, buns and cakes). Moreover, it is widely used in oil production in India out of the total soybean produced about 85 per cent is utilized for oil extraction, 10 per cent for seed and 5 per cent for food purpose.

In India, soybean is grown on an average of $10.96 \mathrm{M}$ ha area with production of 13.46 million metric tonnes having $1228 \mathrm{~kg} \mathrm{ha}^{-1}$ average productivity and $1120 \mathrm{~kg} \mathrm{ha}^{-1}$ average yield [2018-19]. In state wise contribution Madhya Pradesh contributes 59.17 percent that is 6.73 million metric tonnes from $5.24 \mathrm{M}$ ha followed by Maharashtra 38.35 percent that is 4.39 million metric tonnes from $3.93 \mathrm{M}$ ha then Rajasthan 9.44 percent that is 1.16 million metric tonnes from $0.93 \mathrm{M}$ ha [Anonymous 2018-19].

In Maharashtra estimate of soybean production 38.35 percent i.e. 4.39 million metric tonnes from $3.93 \mathrm{M}$ ha with productivity $925 \mathrm{~kg} \mathrm{ha}^{-1}$ [Anonymous, 2018-
19].

Land configuration decides the effectiveness of the crop management practices regarding application of nutrient, irrigation, weed management, etc. Major land configuration practices includes raised bed preparation, rides and furrows, broad bed furrows, etc. The general farmer's practice sowing over flat bed without any proper land configuration, leading to less significant growth and development of crops and in turn lesser yields (Deshmukh et al., 2016). Therefore, it is necessary to know about the suitable land configuration for proper growth and development of crops especially cereals.

\section{Materials and Methods}

A field experiment entitled "Standardization of optimum seed rate and yield maximization in soybean under different land configurations and sowing techniques" was undertaken during kharif, 2018 at Post Graduate Instructional Farm, Mahatma Phule Krishi Vidyapeeth, Rahuri, Dist. Ahmednagar (Maharashtra). The experiment consists of eight treatments involving Preparation of ridges and furrows at $45 \mathrm{~cm}$ distance and sowing at one side $(45 \mathrm{~cm} \times 10 \mathrm{~cm})$, Preparation of ridges and furrows at $45 \mathrm{~cm}$ distance and sowing at both side $(22.5 \mathrm{~cm} \mathrm{x}$ $10 \mathrm{~cm})$, Preparation of ridges and furrows at $60 \mathrm{~cm}$ distance and sowing at one side $(60 \mathrm{~cm}$ $\mathrm{x} 10 \mathrm{~cm})$, Preparation of ridges and furrows at $60 \mathrm{~cm}$ distance and sowing at both side $(30 \mathrm{~cm}$ $\mathrm{x} 10 \mathrm{~cm}$ ), Preparation of ridges and furrows at $90 \mathrm{~cm}$ distance and sowing at both side $(45 \mathrm{~cm}$ $\mathrm{x} 10 \mathrm{~cm})$, Preparation of BBF [90cm top and $120 \mathrm{~cm}$ base] and sowing at $22.5 \mathrm{~cm}$ distance $(22.5 \mathrm{~cm} \times 10 \mathrm{~cm})$. Preparation of BBF [ $90 \mathrm{~cm}$ top and $120 \mathrm{~cm}$ base] and sowing at $30 \mathrm{~cm}$ distance $(30 \mathrm{~cm} \times 10 \mathrm{~cm})$, Flat bed $(45 \mathrm{~cm} \times 10 \mathrm{~cm})$. The experiment was laid out in randomized block design with three replications. The soil was loamy in texture, 
low in available nitrogen (197.5 $\mathrm{kg} \mathrm{ha}^{-1}$ ), medium in available phosphorous $(18.4 \mathrm{~kg}$ ha ${ }^{1}$ ) and very high in potassium (480 $\mathrm{kg} \mathrm{ha}^{-1}$ ). The soil was moderately alkaline in reaction ( $\mathrm{pH} 8.26)$.

\section{Results and Discussion}

The results obtained from the present investigation as well as relevant discussion have been summarized under following heads.

\section{Yield and yield contributing characters}

Data in table 1 revels that the yield contributing characters recorded at harvest viz. number of pod plant $^{-1}$ (56), pod weight plant $^{-1}(16.80 \mathrm{~g})$, weight of seeds $\operatorname{pod}^{-1}(15.36$ g), 100 grain (12 g) weight were obtained highest on $60 \mathrm{~cm}$ ridges and furrows sowing at one side $(60 \mathrm{~cm} \times 10 \mathrm{~cm})$ with seed rate $28.1 \mathrm{~kg} \mathrm{ha}^{-1}$. Ridges and furrow planting favours optimum availability of soil moisture with uniform flow of water. Also the loose and porous soil under ridges and furrow was found to provide better aeration, microbial activity and drainage which give increased yield contributing characters reported by Jadhav et al., (2011) and Lakpale and Tripathi (2012).

Data in table 2 revels that Significantly the highest grain yield ( $\left.30.60 \mathrm{q} \mathrm{ha}^{-1}\right)$, straw yield (38.86 $\left.\mathrm{q} \mathrm{ha}^{-1}\right)$ were recorded on $60 \mathrm{~cm}$ ridges and furrows sowing at two side $(30 \mathrm{~cm} \mathrm{x}$ $10 \mathrm{~cm}$ ) with seed rate $51.4 \mathrm{~kg} \mathrm{ha}^{-1}$. Similar results were also reported by Rajput et al., (1999) and Abbas et al., (1994)

Table.1 Yield contributing characters of soybean influenced by different treatment

\begin{tabular}{|c|c|c|c|c|}
\hline Treatment & $\begin{array}{l}\text { No. of pods } \\
\text { plant }^{-1}\end{array}$ & $\begin{array}{l}\text { Pods weight } \\
\text { plant }^{-1}(g)\end{array}$ & $\begin{array}{l}\text { Weight of seeds } \\
\text { plant }^{-1}(g)\end{array}$ & $\begin{array}{l}100 \text { grain } \\
\text { weight }(g)\end{array}$ \\
\hline $\begin{array}{l}T_{1} \text {-Preparation of ridges and furrows at } 45 \mathrm{~cm} \\
\text { distance and sowing at one side }(45 \mathrm{~cm} \times 10 \mathrm{~cm}) \text {. }\end{array}$ & 51.00 & 15.30 & 13.46 & 11.51 \\
\hline $\begin{array}{l}T_{2} \text {-Preparation of ridges and furrows at } 45 \mathrm{~cm} \\
\text { distance and sowing at both side } \\
(22.5 \mathrm{~cm} \times 10 \mathrm{~cm}) \text {. }\end{array}$ & 34.00 & 10.20 & 6.74 & 9.92 \\
\hline $\begin{array}{l}T_{3}-\text { Preparation of ridges and furrows at } 60 \mathrm{~cm} \\
\text { distance and sowing at one side } \\
(60 \mathrm{~cm} \times 10 \mathrm{~cm}) \text {. }\end{array}$ & 56.00 & 16.80 & 15.36 & 12.00 \\
\hline $\begin{array}{l}\mathrm{T}_{4}-\text { Preparation of ridges and furrows at } 60 \mathrm{~cm} \\
\text { distance and sowing at both side } \\
(30 \mathrm{~cm} \times 10 \mathrm{~cm}) \text {. }\end{array}$ & 40.00 & 12.00 & 9.82 & 10.67 \\
\hline $\begin{array}{l}T_{5}-\text { Preparation of ridges and furrows at } 90 \mathrm{~cm} \\
\text { distance and sowing at both side } \\
(45 \mathrm{~cm} \times 10 \mathrm{~cm}) \text {. }\end{array}$ & 53.00 & 16.57 & 13.50 & 11.53 \\
\hline $\begin{array}{l}\mathrm{T}_{6} \text {-Preparation of } \mathrm{BBF}[90 \mathrm{~cm} \text { top and } 120 \mathrm{~cm} \text { base] } \\
\text { and sowing at } 22.5 \mathrm{~cm} \text { distance }(22.5 \mathrm{~cm} \times 10 \mathrm{~cm}) \text {. }\end{array}$ & 33.60 & 10.08 & 6.65 & 9.90 \\
\hline $\begin{array}{l}T_{7} \text {-Preparation of } B B F[90 \mathrm{~cm} \text { top and } 120 \mathrm{~cm} \\
\text { base }] \text { and sowing at } 30 \mathrm{~cm} \text { distance }(30 \mathrm{~cm} \times 10 \mathrm{~cm}) \text {. }\end{array}$ & 39.20 & 11.76 & 9.50 & 10.59 \\
\hline$T_{8}$-Flat bed $(45 \mathrm{~cm} \times 10 \mathrm{~cm})$ & 49.00 & 14.70 & 11.00 & 10.20 \\
\hline S.E. m $( \pm)$ & 1.01 & 0.44 & 0.26 & 0.49 \\
\hline C.D at $5 \%$ & 3.07 & 1.36 & 0.81 & NS \\
\hline General Mean & 44.48 & 13.43 & 10.75 & 10.79 \\
\hline
\end{tabular}


Table.2 Effect of different land configurations and sowing techniques on yield and economics of soybean

\section{Treatment}

T1-Preparation of ridges and furrows at $45 \mathrm{~cm}$ distance and sowing at one side $(45 \mathrm{~cm} \times 10 \mathrm{~cm})$.

T2-Preparation of ridges and furrows at $45 \mathrm{~cm}$ distance and sowing at both side $(22.5 \mathrm{~cm} \times 10 \mathrm{~cm})$.

T3-Preparation of ridges and furrows at $60 \mathrm{~cm}$ distance and sowing at one side $(60 \mathrm{~cm} \times 10 \mathrm{~cm})$.

T4-Preparation of ridges and furrows at $60 \mathrm{~cm}$ distance and sowing at both side $(30 \mathrm{~cm} \times 10 \mathrm{~cm})$.

T5-Preparation of ridges and furrows at $90 \mathrm{~cm}$ distance and sowing at both side $(45 \mathrm{~cm} \times 10 \mathrm{~cm})$.

T6-Preparation of BBF [90 cm top and $120 \mathrm{~cm}$ base] and sowing at $22.5 \mathrm{~cm}$ distance $(22.5 \mathrm{~cm} \times 10 \mathrm{~cm})$.

T7-Preparation of BBF $[90 \mathrm{~cm}$ top and $120 \mathrm{~cm}$ base $]$ and sowing at $30 \mathrm{~cm}$ distance $(30 \mathrm{~cm} \times 10 \mathrm{~cm})$.

T8-Flat bed $(45 \mathrm{~cm} \times 10 \mathrm{~cm})$

S.E. $\mathbf{m}( \pm)$

C.D at $5 \%$

General Mean

\begin{tabular}{|c|c|c|c|}
\hline $\begin{array}{c}\text { Grain } \\
\text { yield } \\
\left(\mathbf{q} \mathbf{~ h a}^{-\mathbf{1}}\right)\end{array}$ & $\begin{array}{c}\text { Straw yield } \\
\left(\mathbf{q ~ h a} \mathbf{~ h}^{-\mathbf{1}}\right)\end{array}$ & $\begin{array}{c}\text { Net monetary } \\
\text { returns } \\
\left(\mathbf{~ h a}^{-\mathbf{1}}\right)\end{array}$ & B:C ratio \\
\hline 28.50 & 36.48 & 60499 & 2.24 \\
\hline 28.30 & 36.79 & 57248 & 2.12 \\
\hline 24.43 & 31.27 & 48174 & 2.06 \\
\hline 30.60 & 38.86 & 65806 & 2.27 \\
\hline 28.70 & 36.45 & 60993 & 2.24 \\
\hline 27.93 & 36.03 & 56034 & 2.10 \\
\hline 29.64 & 38.53 & 63077 & 2.25 \\
\hline 23.12 & 29.36 & 43431 & 1.96 \\
\hline 0.31 & 0.40 & 1223.32 & \\
\hline 0.96 & 1.24 & 3710.57 & \\
\hline 27.65 & 35.47 & 56883 & 2.15 \\
\hline
\end{tabular}

Table.3 Protein content in soybean as influenced by different treatment

\begin{tabular}{|c|c|}
\hline Treatment & Protein (\%) \\
\hline $\begin{array}{l}T_{1}-\text { Preparation of ridges and furrows at } 45 \mathrm{~cm} \text { distance and sowing at one } \\
\text { side }(45 \mathrm{~cm} \times 10 \mathrm{~cm}) \text {. }\end{array}$ & 40.07 \\
\hline $\begin{array}{l}T_{2} \text {-Preparation of ridges and furrows at } 45 \mathrm{~cm} \text { distance and sowing at both } \\
\text { side }(22.5 \mathrm{~cm} \times 10 \mathrm{~cm}) \text {. }\end{array}$ & 39.80 \\
\hline $\begin{array}{l}T_{3}-\text { Preparation of ridges and furrows at } 60 \mathrm{~cm} \text { distance and sowing at one } \\
\text { side }(60 \mathrm{~cm} \times 10 \mathrm{~cm}) \text {. }\end{array}$ & 40.23 \\
\hline $\begin{array}{l}T_{4} \text {-Preparation of ridges and furrows at } 60 \mathrm{~cm} \text { distance and sowing at both } \\
\text { side }(30 \mathrm{~cm} \times 10 \mathrm{~cm}) \text {. }\end{array}$ & 39.57 \\
\hline $\begin{array}{l}T_{5}-\text { Preparation of ridges and furrows at } 90 \mathrm{~cm} \text { distance and sowing at both } \\
\text { side }(45 \mathrm{~cm} \times 10 \mathrm{~cm}) \text {. }\end{array}$ & 40.10 \\
\hline $\begin{array}{l}\text { T }_{6}-\text { Preparation of BBF }[90 \mathrm{~cm} \text { top and } 120 \mathrm{~cm} \text { base] and sowing at } 22.5 \mathrm{~cm} \\
\text { distance }(22.5 \mathrm{~cm} \times 10 \mathrm{~cm}) \text {. }\end{array}$ & 39.60 \\
\hline $\begin{array}{l}T_{7}-\text { Preparation of } B B F[90 \mathrm{~cm} \text { top and } 120 \mathrm{~cm} \text { base }] \text { and sowing at } 30 \mathrm{~cm} \\
\text { distance }(30 \mathrm{~cm} \times 10 \mathrm{~cm}) \text {. }\end{array}$ & 39.87 \\
\hline$T_{8}$-Flat bed $(45 \mathrm{~cm} \times 10 \mathrm{~cm})$ & 39.23 \\
\hline S.E. $\mathbf{m}( \pm)$ & 0.27 \\
\hline C.D at $5 \%$ & NS \\
\hline General Mean & 39.81 \\
\hline
\end{tabular}




\section{Quality parameters}

\section{Protein content}

The data in respect of protein content of soybean are presented in table 3 . The mean protein content in grain was 39.81 per cent. Numerically maximum protein content was recorded $40.23(\%)$ by treatment preparation of ridges and furrows at $60 \mathrm{~cm}$ distance sowing at one side $(60 \mathrm{~cm} \times 10 \mathrm{~cm})$. which is followed by preparation of ridges and furrows at $90 \mathrm{~cm}$ distance sowing at both side $(45 \mathrm{~cm} \mathrm{x}$ $10 \mathrm{~cm})$ i.e. $40.10(\%)$. Whereas numerically minimum protein content was recorded by flat bed treatment $39.23(\%)$. The protein content in grain was statistically non significant due to different land configurations and sowing techniques.

\section{Economics}

Data in table 2 reveals that the highest gross returns (Rs. $117154 \mathrm{ha}^{-1}$ ) and net monetary returns (Rs. $65806 \mathrm{ha}^{-1}$ ) were recorded on 60 $\mathrm{cm}$ ridges and furrows sowing at two side (30 $\mathrm{cm} \times 10 \mathrm{~cm}$ ) with seed rate $51.4 \mathrm{~kg} \mathrm{ha}^{-1}$. The similar trend was observed in case of benefit: cost ratio. The highest benefit: cost ratio (2.27) recorded with $60 \mathrm{~cm}$ ridges and furrows sowing at two side $(30 \mathrm{~cm} \times 10 \mathrm{~cm})$ with seed rate $51.4 \mathrm{~kg} \mathrm{ha}^{-1}$. Similar results obtained by Hariram et al., (2011), Dhakad et al., (2014) and Prajapati et al., (2018).

In conclusion the yield contributing characters recorded at harvest viz. number of pod plant-1 (56), pod weight plant ${ }^{-1}(16.80 \mathrm{~g})$. Weight of seeds $\operatorname{pod}^{-1}(15.36 \mathrm{~g}), 100$ grain (12 g) weight was obtained highest on $60 \mathrm{~cm}$ ridges and furrows sowing at one side $(60 \mathrm{~cm} \mathrm{x} 10 \mathrm{~cm})$ with seed rate $28.1 \mathrm{~kg} \mathrm{ha}^{-1}$.Significantly the highest grain yield $\left(30.60 \mathrm{q} \mathrm{ha}^{-1}\right)$, straw yield $\left(38.86 \mathrm{q} \mathrm{ha}^{-1}\right)$ were recorded on $60 \mathrm{~cm}$ ridges and furrows sowing at two side $(30 \mathrm{~cm} \mathrm{x}$ $10 \mathrm{~cm}$ ) with seed rate $51.4 \mathrm{~kg} \mathrm{ha}^{-1}$. Sowing of soybean on $60 \mathrm{~cm}$ ridges and furrows at one side $(60 \mathrm{~cm} \times 10 \mathrm{~cm})$ with seed rate $28.1 \mathrm{~kg} \mathrm{ha}^{-1}$ increases protein content. The highest gross returns (Rs.117154 ha-1) and net monetary returns (Rs. $65806 \mathrm{ha}^{-1}$ ) were recorded on 60 $\mathrm{cm}$ ridges and furrows sowing at two side (30 $\mathrm{cm} \times 10 \mathrm{~cm}$ ) with seed rate $51.4 \mathrm{~kg} \mathrm{ha}^{-1}$. The similar trend was observed in case of benefit: cost ratio. The highest benefit: cost ratio (2.27) recorded with $60 \mathrm{~cm}$ ridges and furrows sowing at two side $(30 \mathrm{~cm} \times 10 \mathrm{~cm})$ with seed rate $51.4 \mathrm{~kg} \mathrm{ha}^{-1}$.

\section{References}

Anonymous, 2018. Report of All India Coordinated Research Project on Soybean, Indore.

Abbas M., Singh M.P., Nigam K. B. and Kandalkar. 1994Effect of phosphorus, plant densities and plant type on yield attributing characters of soybean. Indian Journal of Agronomy. 3: 249251.

Deshmukh, S.P., Vasave, J., Patel, A.M. 2016. Short Review of Land Configuration to Improve the Plant Growth, Development and Yield of Cereals. International Journal of Interdisciplinary Research and Innovations. 4(3): 1-4.

Dhakad ,S., Agrawal., V. and Verma, S. 2014. Effect of ridge and furrow system on the growth character and productivity of rainfed soybean in Vidisha district of M.P. Research in Environment and Life Sciences 7(3): 211-212

Hariram, Singh, G., Aggarwal, N. and Kaur, J. 2011. Soybean (Glycine max) growth, productivity and water use under different sowing methods and seeding rates in Punjab. Indian Journal of Agronomy 56 (4): 377-380.

Jadhav, J.A., Patil, D.B. and Ingole, P.G. 2011. Effect of mechanization with different land configuration on 
economics and energetic of soybean. International Journal of Forestry and Crop Improvement, 2(1): 78-80.

Lakpale R. and Tripathi, R.S. 2012. Broadbed furrow and ridge and furrow method of sowing under different seed rates of soybean (Glycine max L.) for high rainfall areas of Chhattisgarh plains. Soybean Research, 10: 52-59.

Prajapati, B.I, Dixit, J.P. and Kulmi, G.S. 2018. Effect of land configurations and weed management practices in soybean. International Journal of Agriculture Sciences. 10(14): 67746776.

Rajput R. L. and Shrivastava U.K. 1999. Influence of varieties, sowing date and seed rate on physiological parameters and seed yield of soybean (Glycine max). Legume Research. 22(2): 117120.

\section{How to cite this article:}

Gadakh, M. D., K. B. Navale, U. S. Surve, Sonal Athnere and Surashe, A. D. 2020. Effect of Different land Configurations and Sowing Techniques on Yield, Yield Attributes, Quality and Economics of Soybean. Int.J.Curr.Microbiol.App.Sci. 9(09): 286-291. doi: https://doi.org/10.20546/ijcmas.2020.909.036 